\title{
HIV prevalence and uptake of HIV/AIDS services among youths (15-24 Years) in fishing and neighboring communities of Kasensero, Rakai District, South Western Uganda
}

Richardson Mafigiri i*, Joseph K. B. Matovu², Fredrick Edward Makumbi ${ }^{2,3}$, Anthony Ndyanabo ${ }^{3}$, Doreen Nabukalu ${ }^{3}$, Moses Sakor ${ }^{3}$, Godfrey Kigozi ${ }^{3}$, Fred Nalugoda ${ }^{3}$ and Rhoda K. Wanyenze ${ }^{2}$

\begin{abstract}
Background: Although fishing communities have a significantly higher HIV prevalence than the general population, there is paucity of data on the burden of HIV and service utilization, particularly among the youth. We assessed the HIV prevalence and utilization of HIV prevention and treatment services among youth in Kasensero fishing community and the neighboring communities.

Method: Data were derived from the Rakai Community Cohort Study (RCCS) surveys conducted between 2013 and 2014. The RCCS is a population-based household survey that collects data annually from individuals aged 15-49 years, resident in 48 communities in Rakai and neighboring districts in Uganda. For this analysis, socio-demographic, behavioral and HIV-related data were obtained for 792 individuals aged 15-24 years. We used logistic regression to conduct bivariate and multivariable analysis to determine the factors that are independently associated with HIV-positive status and their corresponding 95\% confidence intervals. Data were analyzed using STATA version 13.

Results: Overall HIV prevalence was 19.7\% $(n=155)$; higher in Kasensero $(n=141 ; 25.1 \%)$ and Gwanda $(n=8 ; 11 \%)$ than in Kyebe $(n=6 ; 3.9 \%), p<0.001$ and among females $(n=112 ; 26.0 \%)$ than males $(n=43 ; 12.0 \%), p<0.001$. Uptake of HIV testing was high in both HIV-positive $(n=136 ; 89.5 \%)$ and HIV-negative youth $(n=435 ; 92 \%)$. Consistent condom use was virtually non-existent in HIV-positive youth $(n=1 ; 0.6 \%)$ compared to HIV-negative youth $(n=20 ; 4.2 \%)$. Only $22.4 \%$ ( $n=34$ ) of the HIV-positive youth were receiving antiretroviral therapy (ART) in 2013-2014; higher in the HIV-positive females $(n=31 ; 28.4 \%)$ than HIV-positive males $(n=03 ; 6.7 \%)$. Slightly more than half of males $(n=134 ; 53.8 \%)$ reported that they were circumcised; the proportion of circumcised youth was higher among HIV-negative males $(n=122 ; 58 \%)$ than HIV-positive males $(n=12 ; 27.9 \%)$. Factors significantly associated with HIV-positive status included living in Kasensero landing site (adjusted Odds Ratio $[a \mathrm{OR}]=5.0 ; 95 \% \mathrm{Cl}: 2.22-13.01)$ and reporting one (aOR $=5.0$; $95 \% \mathrm{Cl}: 1.33-15.80)$ or $2+$ sexual partners in the past 12 months (aOR $=11.0 ; 95 \% \mathrm{Cl} ; 3.04-36.72$ ).

Conclusion: The prevalence of HIV is high especially among young females and in landing site communities than in the peripheral communities. Uptake of HIV prevention and treatment services is very low. There is an urgent need for youth-friendly services in these communities.
\end{abstract}

Keywords: HIV prevalence, Youth, Services, Care, Uptake

\footnotetext{
* Correspondence: rmafigiri@musph.ac.ug; rmafigiri@gmail.com

'Public Health Fellowship Program (PHFP) - Field Epidemiology Track,

Ministry of Health-Makerere University School of Public Health, P.O. Box 7072,

Kampala, Uganda

Full list of author information is available at the end of the article
}

(c) The Author(s). 2017 Open Access This article is distributed under the terms of the Creative Commons Attribution 4.0 International License (http://creativecommons.org/licenses/by/4.0/), which permits unrestricted use, distribution, and reproduction in any medium, provided you give appropriate credit to the original author(s) and the source, provide a link to the Creative Commons license, and indicate if changes were made. The Creative Commons Public Domain Dedication waiver (http://creativecommons.org/publicdomain/zero/1.0/) applies to the data made available in this article, unless otherwise stated. 


\section{Background}

Despite the general decline in new HIV infections in sub-Saharan Africa (SSA), in 2013 the region was responsible for $72 \%$ of all new HIV infections globally [1]. Thus, the HIV epidemic remains a serious public health problem globally and especially in SSA [2]. With a prevalence of $7.3 \%$, Uganda had an estimated 1.6 million HIV infected people in 2013 [3]. HIV prevalence among individuals aged $15-24$ was $3.7 \%$ and more than twice as high among females than males [4]. Youth in Uganda contribute more than $50 \%$ of the total population [5], and are thus an important population to target in HIV prevention given this high HIV prevalence.

An estimated 4.2 million people living with HIV globally are youth 15-24 years and the burden is highest among females [6]. There is concern of increase in risky sexual behaviours such as multiple sexual partners and decline in condom use among youth in many SSA countries $[7,8]$. Several reasons have been advanced for this increase in risky sexual behaviors including reduced focus on primary HIV prevention in the era of antiretroviral therapy scale up [9-11]. The youth are especially vulnerable in this respect as they have limited or no historical knowledge or experience with HIV [12, 13].

Access to HIV treatment increased dramatically, from $7 \%$ in 2003 to approximately $46 \%$ of adults and $49 \%$ of children by end of 2015 [14-16]. In SSA, approximately $36.6 \%$ of those in need of treatment are able to access ART compared to $2 \%$ in 2003 [17]. However, this improvement is not equitable as the most vulnerable and high-risk groups remain grossly underserved. People living in fishing communities are among such high-risk groups that have not received adequate attention [18-20]. Uganda included fishing communities among the key population groups that were recommended for test and treat in the revised guidelines in 2013 but it is not clear if this policy shift has yielded the desired outcomes in terms of improved access to HIV treatment among this populations, and especially the young people [21].

Fishing is an important commercial enterprise and a means of survival to many Ugandans. Uganda has several lakes including Lake Victoria (the third largest Lake in the world), Lake Kyoga, George, Edward, and Albert and several large rivers (including River Nile), all of which have fishing communities and landing sites [22]. The fisheries industry was estimated to yield approximately $12 \%$ of the agricultural Gross Domestic Product (GDP) and 2.5\% of the national GDP in 2011. About 1.2 million people in Uganda directly depend on fisheries industry as their main source of income [23]. An estimated 400,000 people are engaged in secondary activities such as fish processing, trading and other services and 100,000 fishermen are directly involved in fish harvest, boat and gear ownership [24]. Fishing in Kasensero communities is artisanal in nature, involving a large number of unskilled workers. A number of school going children work in the fisheries sub-sectors to earn a living [25], and $90 \%$ of fishermen are $<40$ years of age [26].

In Uganda, Human Immunodeficiency Virus (HIV) was first reported at Kasensero landing site in Rakai district, in the South Western region in 1982 [27, 28]. The district has continued to experience high HIV rates at $12 \%$ compared to the national average of $7.3 \%[27,29]$. Rakai district has a large fishing community population with identifiable high risk behaviors and limited access to health services as described in other fishing communities [19, 30, 31]. Youth in fishing communities, especially females, have a much higher HIV prevalence than youth in the general population [32]. However, most studies conducted in fishing communities have focused on risky sexual behaviors among adults and not much on access to HIV prevention and care services, especially among youth $[18,33,34]$. The objective of our study was to document HIV prevalence, risky sexual behaviors, and access to HIV prevention and treatment services, among youth in Kasensero fishing and the neighboring communities of Gwanda and Kyebe between 2013 and 2014.

\section{Methods}

\section{Study design \& site}

This was a cross-sectional analysis of quantitative secondary data for youth aged 15-24 years who were interviewed as part of the Rakai Community Cohort Study (RCCS) surveys between 2013 and 2014. The RCCS has been described previously $[35,36]$. Briefly, the RCCS is a household, population-based survey which was instituted by the Rakai Health Sciences Program (formerly Rakai Project) in 1994 for a community randomised trial for control of sexually transmitted diseases (STD) to prevent HIV. The RCCS conducts annual socio-demographic, sero-behavioral and reproductive health interviews in a cohort of approximately $\sim 18,000$ individuals aged 15-49 years, resident in 48 study communities [35]. In the 2013-2014 survey visits, adults aged 15-49 years who consented to interviews were requested to participate in RCCS. Consenting individuals were requested to provide a blood sample for HIV testing, which was done using rapid diagnostic tests (RDTs) in line with the national HIV testing algorithm [37]. The RCCS offers antiretroviral therapy at participating government health clinics within the study communities [38] and offers medical male circumcision services to non-Muslim men [39], among other HIV services.

\section{Study context}

This paper uses data collected from Kasensero community; one of the 48 RCCS study communities in Rakai. The first HIV/AIDS cases in Uganda were identified at two landing sites of Kasensero and Lukunyu in 1982 
[28]. Since then, HIV prevalence has remained high in these communities [40] but with limited access to HIV services [41]. Kasensero fishing community consists of three sub-counties of Kasensero landing site, Gwanda and Kyebe in Rakai district southwestern Uganda, approximately $200 \mathrm{~km}$ from the capital city Kampala. The population of approximately 18,000 people is largely mobile and depends directly or indirectly on fishing. The community includes fishermen, boat owners, fish processors, boat builders, fishing gear makers and repairers, retail traders and other casual income earners [32]. Kasensero fishing community is served by two health facilities, which offer HIV prevention, care, and treatment serves [32]. Kasensero community borders the United Republic of Tanzania to the south and Lake Victoria in the East.

\section{Study population}

The study was conducted among 792 individual aged 15-24 years (youth) residents in Kasensero fishing community in Rakai District, southwestern Uganda. The number of youth in this analysis represents 12\% (792/ 6406) of all the youth in the RCCS cohort. The term 'youth' is used to denote a period of transition from childhood and dependence to independence and adulthood, a stage that comes with several social and behavioral challenges and vulnerability [42]. Whereas the United Nations defines youth as 12-24 years, the dataset for this analysis was obtained from individuals aged 15-24 years since the RCCS cohort enrolls individuals in the age group 15-49 years [35].

\section{HIV diagnosis}

HIV diagnosis was done using rapid HIV testing algorithm as recommended by the Ministry of Health $(\mathrm{MoH})$, and confirmed by enzyme immunoassays (EIAs) for seroincident cases. Parallel testing with Determine and Stat-Pak was conducted and reported as negative or positive if both tests were negative or positive, respectively. In case of discordance of the two tests, a third test was performed with Uni-Gold and reported as positive if it agreed with either of the two tests. A weak Uni-Gold test (weak positive) was repeated with EIA. Negative tests on second EIA were retested with Polymerase Chain Reaction (PCR).

\section{Measures}

The dependent variable for our study is the HIV status and the independent variables were socio-demographic characteristics (age, sex, marital status and occupation), sexual behaviors (number of sexual partners reported in the past 12 months prior to the interview), and utilization of preventive (condom use and medical male circumcision) and care services (HIV testing, ART). Data were collected using structured questionnaires administered in private by trained same-sex interviewers. Marriage was defined as all forms of marriage including those married in church, mosque or cohabiting. Occupation was defined as any work where a participant earns a living. Three occupation categories were created, including: "fishing" (to designate those involved in the activity of fishing); "business" (selling other items at the landing site and neighboring communities, selling in shops, bars) and "other activities" which included agriculture for home and commercial use, house worker bar workers, waiter, hair dresser, construction, government and transport services. Education level was assessed based on the highest level of education attained; and was categorized as: uneducated ("none"/"no schooling"), "primary" if one had some level of primary or completed primary level at most, and "post-primary" for respondents who attained secondary and other tertiary education. The variable "illicit drug use" was used to define the use of unlawful drugs such as marijuana, cocaine and others. An individual was categorized as using 'illicit drugs' if they reported using at least one of these drugs. Alcohol use before sex was defined as drinking alcohol (beer, local brew and spirits) before sexual intercourse. Exchange of gifts for sex was defined as accepting or receiving a gift in order to have sexual intercourse. Condom use was assessed as the use of condoms: i) all the time (always), ii) some of the time or iii) never in the twelve months prior to the survey. Individuals who reported using condoms all the time with every sexual partner were considered to have used condoms consistently while those who did not use condoms with all partners all the time were categorized as "inconsistent" users. Other variables included HIV testing, use of ART among those who were HIV-positive and medical male circumcision. Medical male circumcision was assessed among non-Muslim males.

\section{Statistical analysis}

Respondents' characteristics were summarized and descriptive analysis was conducted to determine proportions of the different variables. Chi-square tests were performed to determine differences in proportions. Bivariate analyses were used to compute the unadjusted associations between the HIV status and independent variables including risky sexual behaviours, sociodemographic characteristics (such as education, religion, and occupation), and other variables (HIV testing and circumcision among non-Muslim males). Variables that were significant at the bivariate analysis $(p<0.05)$ were considered for the multivariable analysis. We conducted multivariable logistic regression by using variables that were significant at the bivariate analysis (communities, gender, education levels, occupation, marital status, number of sex partners and gift for sex). Backward selection into specific models was conducted for variables such as number of sexual partners, alcohol use before 
sex, demographic, gift for sex, occupation, and religion [43]. Analysis was performed using Stata 13 (StataCorp, College Station, TX) software.

\section{Ethics statement}

The Science and Ethics Committee of Uganda Virus Research Institute (UVRI), the Uganda National Council of Science and Technology, and the US-based WESTERN IRB approved the RCCS.

\section{Results}

\section{Characteristics of respondents}

Table 1 shows the socio-demographic characteristics of the 792 individuals aged 15-24 who were included in the analysis. The mean age of the respondents was 20.5 years for both sexes. Respondents' mean age was similar across the three communities: $19.06 \pm 2.8$ years in Kyebe; $20.9 \pm 3$ in Kasensero and $19.8 \pm 2.4$ in Gwanda. Slightly more than half of the respondents $(54.7 \%, n=433)$ were females; between 64.5 and $71.4 \%$ of the respondents had no formal education and nearly two-thirds $(65 \%, n=515)$ were Catholics. Fishing as an occupation was mentioned more by those living at Kasensero landing site than in the neighboring communities. A higher percentage $(31 \%, n=175)$ of youth in Kasensero landing site had two or more sexual partners compared to those in the neighboring communities. A higher proportion of youth $(5 \%, n=28)$ in Kasensero reported use of illicit drugs (heroin, marijuana and cocaine) compared to those in Gwanda and Kyebe (1\%).

\section{HIV prevalence and determinants of HIV positive status among the youth}

Table 2 shows the HIV prevalence among 789 youth for whom complete HIV status data were available, stratified by sex. Overall, HIV prevalence was high across the three communities $(19.6 \% ; n=155)$; but much higher at Kasensero landing site $(23.6 \%, n=598)$ than in Gwanda $(11 \%, n=73)$ and Kyebe (3.9\%, $n=155) ; p<0.001$. Female respondents had a higher HIV prevalence $(25.9 \% n=112)$ than their male counterparts $(12 \% n=43), P<0.001$. The higher HIV prevalence in females than males was consistent across study communities, level of education, number of self-reported sexual partners in the past 12 months and marital status. For instance, HIV prevalence among females living at Kasensero landing site was more than twice as high as that for males resident in the same locality (females: $34.4 \%$ relative to males: $14.1 \% ; p<0.001$ ). Also, HIV prevalence among females reporting $2+$ sexual partners in the past 12 months was about three times as high as that for males reporting the same number of sexual partners (females: $53.6 \%$ than males: $18.3 \% ; p<0.001$ ). Respondents with post-primary education had a higher HIV prevalence $(30 \%, n=14)$ than those with
Table 1 Demographic and socio-behavioral characteristics of 792 youth by community in Kasensero fishing communities

\begin{tabular}{|c|c|c|c|c|}
\hline \multirow[t]{2}{*}{ Variables } & Kasensero & Gwanda & Kyebe & \multirow[t]{2}{*}{$P$ - Value } \\
\hline & $N=564(\%)$ & $N=73(\%)$ & $N=155(\%)$ & \\
\hline \multicolumn{4}{|l|}{ Gender } & 0.310 \\
\hline Female & $302(54.0)$ & $46(63.0)$ & $85(55.0)$ & \\
\hline Male & $262(46.0)$ & $27(37.0)$ & $70(45.0)$ & \\
\hline \multicolumn{4}{|l|}{ Education } & 0.002 \\
\hline Uneducated & $403(71.4)$ & $49(67.1)$ & $100(64.5)$ & \\
\hline Primary & $120(21.3)$ & $19(26.0)$ & $53(34.2)$ & \\
\hline Post-primary & $41(7.3)$ & $5(7.0)$ & $2(1.3)$ & \\
\hline \multicolumn{4}{|l|}{ Religion } & $<0.001$ \\
\hline Catholic & $329(58.3)$ & $58(79.4)$ & $128(83.0)$ & \\
\hline Protestant & $80(14.2)$ & $7(10.0)$ & $7(4.5)$ & \\
\hline Muslim & $108(19.2)$ & $4(5.0)$ & $13(8.4)$ & \\
\hline Other religion ${ }^{a}$ & $47(8.3)$ & $4(5.5)$ & $7(4.5)$ & \\
\hline \multicolumn{4}{|l|}{ Occupation } & $<0.001$ \\
\hline Business & $174(30.9)$ & $18(24.7)$ & 18 (11.6) & \\
\hline Fishing & $98(17.4)$ & $3(4.1)$ & $1(0.7)$ & \\
\hline Other occupation ${ }^{\text {b }}$ & $292(51.8)$ & $52(71.2)$ & $136(87.7)$ & \\
\hline \multicolumn{4}{|l|}{ Marital status } & $<0.001$ \\
\hline Married & $271(48.0)$ & $32(44.0)$ & $48(31.0)$ & \\
\hline Not married & $293(52.0)$ & $41(56.0)$ & $107(69.0)$ & \\
\hline \multicolumn{4}{|c|}{ Number of sexual partners in the past 12 months } & $<0.001$ \\
\hline 0 & $77(14.0)$ & $20(27.4)$ & $68(44.0)$ & \\
\hline 1 & $312(55.3)$ & $46(63.0)$ & $73(47.1)$ & \\
\hline $2+$ & $175(31.0)$ & $7(9.6)$ & $14(9.0)$ & \\
\hline \multicolumn{4}{|l|}{ Illicit Drug use } & 0.023 \\
\hline Yes & $28(5.0)$ & $1(1.4)$ & $1(1.0)$ & \\
\hline No & $536(95.0)$ & $72(99.0)$ & $154(99.0)$ & \\
\hline \multicolumn{4}{|l|}{ Gift for sex } & 0.060 \\
\hline Yes & $19(3.5)$ & $1(2.0)$ & $0(0.0)$ & \\
\hline No & $532(96.5)$ & $65(98.5)$ & $143(100)$ & \\
\hline \multicolumn{4}{|l|}{ Alcohol before sex } & 0.008 \\
\hline Yes & $15(3.0)$ & $1(2.0)$ & $0(0.0)$ & \\
\hline No & $536(97.3)$ & 65 (98.5) & $143(100)$ & \\
\hline
\end{tabular}

${ }^{\mathrm{a} O t h e r ~ r e l i g i o n ~ i n c l u d e s ~ A d v e n t i s t s ~ a n d ~ S a v e d / B o r n-a g a i n ; ~}{ }^{\mathrm{b}}$ Other occupation includes agriculture for home use and commercial, transport, security officer, government worker, students and bar workers

primary $(14.7 \%, n=28)$ or no formal education at all (20.5\%, $n=113) ; P=0.042$. Participants with two or more sexual partners had higher HIV prevalence $(30.8 \%, n=60)$ than those with one sexual partner $(22 \%, n=92)$ or those who reported no sexual partner in the past twelve months $(5.3 \%, n=3)$.

Table 3 shows results of the bivariate and multivariable logistic regression of HIV-positive status by selected socio-demographic and behavioral characteristics. The 
Table 2 HIV prevalence by selected socio-behavior characteristics, stratified by sex, among $789^{\mathrm{a}}$ youth from Kasensero fishing community, Rakai district

\begin{tabular}{|c|c|c|c|c|c|}
\hline \multirow[t]{2}{*}{ Variable } & \multicolumn{2}{|c|}{ Female $(N=431)$} & \multicolumn{2}{|c|}{ Male $(N=358)$} & \multirow[t]{2}{*}{$P$-value } \\
\hline & Total & $n(\%)$ & Total & $n(\%)$ & \\
\hline \multicolumn{5}{|l|}{ Community } & $<0.001$ \\
\hline Kyebe & 85 & $4(4.7)$ & 70 & $2(2.8)$ & \\
\hline Gwanda & 46 & $4(8.7)$ & 27 & $4(14.8)$ & \\
\hline Kasensero & 300 & $104(34.4)$ & 261 & $37(14.1)$ & \\
\hline \multicolumn{5}{|l|}{ Education } & 0.042 \\
\hline Uneducated & 289 & $81(28.0)$ & 262 & $32(12.2)$ & \\
\hline Primary & 111 & $19(17.1)$ & 80 & $9(11.3)$ & \\
\hline Post-primary & 31 & $12(38.7)$ & 16 & $2(12.5)$ & \\
\hline \multicolumn{5}{|l|}{ Occupation } & 0.032 \\
\hline Business & 140 & 47 (33.6) & 69 & $6(8.7)$ & \\
\hline Fishing & 1 & $0(0.0)$ & 101 & $21(20.8)$ & \\
\hline Other occupation ${ }^{\mathrm{b}}$ & 290 & $65(22.4)$ & 188 & $16(8.5)$ & \\
\hline \multicolumn{5}{|l|}{ Marital status } & $<0.001$ \\
\hline Married & 261 & $76(29.1)$ & 90 & $22(24.4)$ & \\
\hline Unmarried & 170 & $36(21.2)$ & 268 & $21(7.8)$ & \\
\hline \multicolumn{5}{|c|}{ Number of sexual partners in the past 12 months } & $<0.001$ \\
\hline 0 & 57 & $3(5.3)$ & 108 & $0(0.0)$ & \\
\hline 1 & 305 & $72(23.6)$ & 124 & $20(16.1)$ & \\
\hline $2+$ & 69 & $37(53.6)$ & 126 & $23(18.3)$ & \\
\hline \multicolumn{5}{|l|}{ Religion } & 0.662 \\
\hline Catholic & 272 & $74(27.2)$ & 242 & $31(12.8)$ & \\
\hline Protestant & 53 & $12(22.6)$ & 40 & $7(17.5)$ & \\
\hline Muslim & 70 & $19(27.1)$ & 54 & $4(7.4)$ & \\
\hline Other religion $^{c}$ & 36 & $7(19.4)$ & 22 & $1(4.6)$ & \\
\hline \multicolumn{5}{|l|}{ Illicit drug use } & 0.675 \\
\hline Yes & 3 & $2(67.0)$ & 27 & $3(11.1)$ & \\
\hline No & 428 & $110(25.7)$ & 331 & $40(12.1)$ & \\
\hline \multicolumn{5}{|l|}{ Gift for sex } & 0.021 \\
\hline Yes & 6 & $2(33.3)$ & 14 & $6(42.9)$ & \\
\hline No & 398 & $106(26.6)$ & 339 & $35(10.3)$ & \\
\hline \multicolumn{5}{|l|}{ Alcohol before sex } & 0.070 \\
\hline Yes & 4 & $1(25.0)$ & 12 & $5(41.7)$ & \\
\hline No & 400 & $107(26.8)$ & 341 & $36(10.6)$ & \\
\hline
\end{tabular}

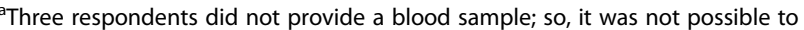
determine their HIV status

bother occupation includes agriculture for home use and commercial, transport, security officer, government worker, students and bar workers

'Other religion includes Adventists and Saved/Born-again

factors that were significantly associated with HIV-positive status at the bivariate analysis included residence at Kasensero landing site, being male, being unmarried, and reporting one (1) or 2 or more (2+) sexual partners in the past 12 months. After adjusting for potential confounders, the factors that remained significantly associated with HIV- positive status included residence at Kasensero landing site when compared to residence in the neighboring communities (adjusted Odds Ratio [aOR] = 5.0, 95\% CI, 2.22-13.01); having one $(\mathrm{aOR}=5.0(95 \% \mathrm{CI}, 1.33-15.80)$ or two or more sex partners $(\mathrm{aOR}=11.0$ (95\% CI: 3.04-36.72); being male $(\mathrm{aOR}=0.4(95 \% \mathrm{CI}, 0.26-0.57)$, and being unmarried $(\mathrm{aOR}=0.4$ (95\% CI, 0.27-0.56).

Table 4 shows HIV service utilization stratified by HIV status. Utilization of HIV testing services was high in both HIV-positive $(n=136 ; 87.1 \%)$ and HIV-negative youth $(n=435 ; 92 \%)$. However, regardless of HIV status, utilization of HIV testing services among females was much higher $(62.7 \%, n=358)$ than males $(37.3 \%, n=213)$. Consistent condom use was very low among both HIVpositive $(n=1 ; 0.6 \%)$ and HIV negative youth $(n=20$; $4.2 \%)$. A higher proportion $(70 \%, n=14)$ of youth who were HIV-negative reported that they did not use condoms in the past twelve months compared to $30 \%(n=6)$ of HIV-positive youth. Only $22.4 \%(n=34)$ of the HIVpositive youth were receiving ART between 2013 and 2014; with a much higher proportion of HIV-positive females $(n=31 ; 28.4)$ compared to HIV-positive males $(n$ $=3 ; 6.7 \%)$ reporting so. Slightly more than half of nonMuslim males $(n=134 ; 53.8 \%)$ reported that they were circumcised; with a higher proportion of HIV-negative males $(n=122 ; 58 \%)$ than HIV-positive males $(n=12$; $27.9 \%)$ reporting so.

\section{Discussion}

In this study in which we assessed the burden of HIV and utilization of HIV prevention and treatment services, we found that nearly $20 \%$ of youth in the fishing communities were living with HIV; with a higher proportion of females living with HIV than males. The overall prevalence in these communities was much higher than the national HIV prevalence average for young people in the general population in Uganda (3.7\%) [21]. HIV prevalence was much higher at the landing site than the peripheral communities. The high HIV prevalence at the landing site may be due to the migratory nature of the population based on seasonality of fish yield $[44,45]$. The higher HIV prevalence among females clearly highlights the vulnerability of younger women to HIV infection [46].

One of the reasons HIV prevalence remains high in fishing communities is because the fisher-folks tend to engage in high risk sex, as evidenced by our findings in this study. In a meta-analysis and systematic review of HIV risky sex behaviours among fishermen, Smolak [47] reported high proportions of the fisher-folk engaging in sex with more sexual partners or in transactional sex. Indeed, in our study, we found that having two or more sexual partners was significantly associated with HIV infection. In another study conducted among 
Table 3 Bivariate and multivariable logistic regression of HIV-positive sero-status and selected characteristics among 789 participants from Kasensero and surrounding fishing communities

\begin{tabular}{|c|c|c|c|c|}
\hline Variable & Crude Odds Ratio (COR) and (95\% Confidence Interval (CI)) & $P$-value & Adjusted Odds Ratio (aOR) and (95\% Cl) & $P$-value \\
\hline \multicolumn{5}{|l|}{ Community } \\
\hline Kyebe & 1.0 & & 1.0 & \\
\hline Gwanda & $3.1(1.02-9.16)$ & 0.046 & $2.1(0.65-6.80)$ & 0.211 \\
\hline Kasensero & $8.3(3.61-19.30)$ & $<0.001$ & $5.0(2.22-13.01)^{\mathrm{a}}$ & $<0.001$ \\
\hline \multicolumn{5}{|l|}{ Sex } \\
\hline Female & 1.0 & & 1.0 & \\
\hline Male & $0.4(0.26-0.57)$ & $<0.001$ & $0.3(0.16-0.50)^{a}$ & $<0.001$ \\
\hline \multicolumn{5}{|l|}{ Education } \\
\hline Uneducated & 1.0 & & 1.0 & \\
\hline Primary & $0.7(0.42-1.05)$ & 0.077 & $0.8(0.46-1.30)$ & 0.287 \\
\hline Post-primary & $1.6(0.85-3.17)$ & 0.139 & $1.2(0.57-2.63)$ & 0.601 \\
\hline \multicolumn{5}{|l|}{ Occupation } \\
\hline Business & 1.0 & & 1.0 & \\
\hline Fishing & $0.8(0.43-1.43)$ & 0.354 & $1.3(0.61-2.71)$ & 0.520 \\
\hline Other occupation & $0.6(0.41-0.88)$ & 0.011 & $0.9(0.605-2.70)$ & 0.704 \\
\hline \multicolumn{5}{|l|}{ Marital status } \\
\hline Married & 1.0 & & 1.0 & \\
\hline Unmarried & $0.4(0.27-0.56)$ & $<0.001$ & $0.6(0.41-0.98)^{a}$ & 0.044 \\
\hline \multicolumn{5}{|c|}{ Number of sexual partners in the past 12 months } \\
\hline 0 & 1.0 & & 1.0 & \\
\hline 1 & $15(4.6-47)$ & $<0.001$ & $5.0(1.33-15.80)^{\mathrm{a}}$ & 0.017 \\
\hline $2+$ & $24(7.4-78)$ & $<0.001$ & $11.0(3.04-36.72)^{a}$ & $<0.001$ \\
\hline \multicolumn{5}{|l|}{ Religion } \\
\hline Catholic & 1.0 & & 1.0 & \\
\hline Protestant & $1.0(0.57-1.73)$ & 1.000 & $0.7(0.37-1.22)$ & 0.190 \\
\hline Muslim & $0.9(0.54-1.46)$ & 0.639 & $0.7(0.407-1.20)$ & 0.211 \\
\hline Other religion & $0.6(0.29-1.35)$ & 0.233 & $0.5(0.23-1.22)$ & 0.136 \\
\hline \multicolumn{5}{|l|}{ Illicit Drug use } \\
\hline Yes & 1.0 & & 1.0 & \\
\hline No & $1.2(0.51-3.30)$ & 0.676 & $1.4(0.47-3.91)$ & 0.569 \\
\hline \multicolumn{5}{|l|}{ Gift for sex } \\
\hline Yes & 1.0 & & 1.0 & \\
\hline No & $0.4(0.14-.88)$ & 0.026 & $0.6(0.22-1.70)$ & 0.334 \\
\hline
\end{tabular}

${ }^{\mathrm{a}}=$ significant

fishing communities, Asiki et al. [48] found low condom use with partners of known HIV status and high episodes of unprotected sex under the influence of alcohol and drugs. Underlying drivers such as high mobility, high disposable income, alcohol and drug use have been cited among the risks in this population [26]. Thus, these findings are consistent with previous studies in fishing communities and highlight the urgent need to scale up effective HIV prevention interventions among young people in these communities $[18,19]$. The findings also indicate a need to pay particular attention to the young girls in relation to HIV prevention.

Consistent with other studies, HIV testing and access to treatment were higher among females than males $[49,50]$. In a prior study conducted in the fishing communities of Kasensero, Lubega et al. found higher HIV services utilization among females than males and attributed this to the intensified services provision by the Rakai Health Sciences Program (RHSP) and the counselling offered at clinics [32]. However, although our study 
Table 4 HIV services uptake, stratified by HIV status, among youth who were sexually active in the last twelve months prior to the interviews $(n=624)$

\begin{tabular}{|c|c|c|c|c|c|}
\hline \multirow[t]{2}{*}{ Variables } & \multicolumn{2}{|l|}{ HIV positive } & \multicolumn{2}{|l|}{ HIV negative } & \multirow[t]{2}{*}{ Total n (\%, } \\
\hline & Female n (\%) & Male n (\%) & Female n (\%) & Male n (\%) & \\
\hline \multicolumn{6}{|c|}{ HIV testing in last 12 months } \\
\hline Yes & $101(92.7)^{a}$ & $35(81.4)^{\mathrm{a}}$ & $257(96.9)$ & $178(85.9)$ & $571(91.5)$ \\
\hline No & $8(7.3)$ & $8(18.6)$ & $8(3.02)$ & $29(14.0)$ & $53(8.5)$ \\
\hline \multicolumn{6}{|c|}{ Condom use in last 12 months } \\
\hline Always & $1(1.0)^{\mathrm{a}}$ & $0(0.0)$ & $4(1.5)$ & $16(7.7)$ & $21(3.4)^{\mathrm{a}}$ \\
\hline Sometime & $103(94.5)^{a}$ & $42(97.7)^{a}$ & $251(94.7)$ & $187(90.3)$ & $583(93.4)$ \\
\hline Never & $5(4.6)^{a}$ & $1(2.3)$ & $10(3.8)$ & $4(1.9)$ & $20(3.2)$ \\
\hline \multicolumn{6}{|c|}{ Antiretroviral therapy } \\
\hline Yes & $31(28.4)^{\mathrm{a}}$ & $3(6.9)^{a}$ & - & - & $34(22.4)$ \\
\hline No & $78(71.6)^{\mathrm{a}}$ & $40(93.0)^{\mathrm{a}}$ & - & - & $118(77.6)$ \\
\hline \multicolumn{6}{|c|}{ Medical male Circumcision } \\
\hline Yes & - & $12(27.9)$ & - & $122(58.0)$ & $134(53.8)^{a}$ \\
\hline No & - & $31(72.1)^{\mathrm{a}}$ & - & $85(41.1)$ & $116(49.2)$ \\
\hline
\end{tabular}

revealed higher HIV service utilization among females than males, the coverage of HIV services especially ART, is generally still below the national and global 90-90-90 targets. Coverage of prevention interventions including condom use among the sexually active and medical male circumcision among young people is also significantly below the national targets $[51,52]$. A number of factors including stigma, inconvenient working hours for the highly mobile fisher-folk, and limited health infrastructure and HIV services have been cited for the low access to HIV care and prevention services in these communities $[33,53]$. This is also coupled with a number of factors such as people travelling long distances to access health facilities, lack of information concerning services provided at health facilities and lack of privacy that is much needed by the youth [54]. Our findings highlight a need to review and enhance HIV service delivery among young people in these communities.

While medical male circumcision (MMC) can reduce the risk of HIV infection by up to $60 \%[55,56]$, in our study, only about $54 \%$ of the non-Muslim youth reported that they were circumcised. Although this percentage is higher than the national average of $26 \%$, it is still below the national target of $80 \%$ and could be further scaled up through community awareness campaigns [21, 57]. Our findings show that the proportion of circumcised youth was higher among HIV-negative males than HIV-positive males. This could be due to the protective effect of circumcision or encouragement of the negative men to circumcise for prevention.

Consistent condom use was especially very low and should be emphasized among the sexually active young people, even with the scale-up of circumcision and other prevention interventions. Fishing communities are known for high alcohol consumption which is a major driver of HIV infection [22, 45, 58, 59]. Alcohol consumption may interfere with consistent condom utilization among sexually active youth hence increasing risk of HIV infection [60]. A systematic review conducted by the World Health Organisation (WHO) reported very low use of condoms among young people in the developing countries where HIV is endemic [61]. A study done by Luciana and colleague among people with known HIV-positive status also indicated a high rate of risky sexual behaviours with inconsistent condom use [62]. Our findings suggest a need for prevention programs to integrate and enhance consistent condom use among youth in fishing communities.

\section{Limitation of the study}

This study had a number of limitations. The data did not include young people below the age of 15 years and did not explore the barriers to service uptake. Additionally, our data did not include sexual partner type, in particular homosexual partnerships which have been associated with HIV risk among young people. These are areas for further research. However, the strengths of this study include use of up-to-date household data among young people including their risky sexual behaviors, HIV service uptake, and their HIV status data for a more objective outcome assessment. The data highlight a huge burden of HIV with suboptimal service coverage and thus an urgent need to scale access to services in this vulnerable group. 


\section{Conclusion}

There is very high HIV prevalence among youth in Kasensero fishing and the neighboring communities, especially among young females with low uptake of HIV prevention and treatment services. We recommend scale up of intensified combination of prevention interventions including awareness, condom use, male circumcision, HIV testing and treatment for HIV infected youth in fishing communities. Expansion of youth friendly services should be prioritized for these communities.

\begin{abstract}
Abbreviations
AIDS: Acquired immunodeficiency syndrome; aOR: Adjusted odds ratio; ART: Antiretroviral Therapy; CDC: Center for diseases control and prevention; $\mathrm{Cl}$ : Confidence interval, EIA: enzyme-immunoassay; HIV: Human immunodeficiency virus; IRB: Institutional review board; MARPS: Most at risk populations; MMC: Medical male circumcision; $\mathrm{MoH}$ : Ministry of health; NIH: National institutes of health; RCCS: Rakai community cohort study; RDT: Rapid diagnostic test; RHSP: Rakai health sciences program; SSA: Sub-Saharan Africa; UPHFP: Uganda public health fellowship program; UVRI: Uganda virus research institute
\end{abstract}

\section{Acknowledgement}

We would like to thank the Rakai Health Sciences Program for allowing us access to their data from this paper; PHFP for the training and technical support, and all the field epidemiology fellows (cohort 2015) for guidance. I wish to acknowledge the support and technical support provided by the U.S Centers for Disease Control and Prevention, which funds the Field Epidemiology Program.

\section{Funding}

Funding for data collection by the RCCS was provided by the US national institutes of health/national institute of allergy and infectious diseases $(\mathrm{NIH} /$ NIAID) (grant number RO1Al114438) and Bill and Melinda Gates. Also funding for data analysis for this study was provided by Center for Disease Control and Prevention (CDC) and the Uganda Public Health Fellowship Program (PHFP).

\section{Availability of data and materials}

Through the RHSP Program Director, the dataset from which this analysis was based could be availed if needed.

\section{Authors' contributions}

RM had primary responsibility for the final content. FEM, GK, FN, SM were all involved in this study from design, data analysis and interpretation of results. JKBM and RKW contributed to the interpretation of results, writing of the manuscript, and reviewed the paper for substantial intellectual content. AN, and DN were responsible for data extraction from the organisations'dataset at RHSP. All co-authors participated in writing, reading and approved the final manuscript.

\section{Author details}

RM holds a Master of Science and is a Field Epidemiology Fellow at the Makerere University School of Public Health. JKBM is a PhD candidate, Honorary Lecturer and the Training Manager for the Fellowship Program at Makerere University School of Public Health. FEM holds a PhD and is an Associate Professor at, Makerere University College of Health Sciences, School of Public Health. DN and AN, hold Master of Science degrees and are Biostatisticians and Data Managers at Rakai Health Sciences Program. GK holds a PhD and is the Training and Research Manager at Rakai Health Sciences Program. FN holds a PhD and is the Director of Rakai Health Sciences Program. RKW holds MBChB with a PhD; she is an Associate Professor and Director of the Fellowship Program at Makerere University School of Public Health.

\section{Competing interests}

We declare that we have no conflict of interest as far as this study is concerned.

\section{Consent for publication}

Not applicable.

\section{Ethical approval and consent to participate}

This study used secondary data that were obtained from the on-going RCCS. RCCS received approval from the Research and Ethics Committee of Uganda Virus Research Institute (UVRI), the Uganda National Council of Science and Technology (\#HS540), and the US-based WESTERN IRB (\#20031318). RCCS participants provided written informed consent to participate in this study and were informed of study benefits and risks before agreeing to participate. Participants were free to withdraw from the study without losing the benefits arising from the study such as free condoms, medical care and health education services. The dataset was received without identifiers of the participants and was not shared with any other parties.

\section{Disclaimer}

The views expressed in this article are those of the authors and do not necessarily represent the official position of the US Centres for Disease Control and Prevention (US CDC), Rakai Health Sciences Program (RHSP), Makerere University School of Public Health (MakSPH), and Ministry of Health.

\section{Publisher's note}

Springer Nature remains neutral with regard to jurisdictional claims in published maps and Institutional affiliations.

\section{Author details}

${ }^{1}$ Public Health Fellowship Program (PHFP) - Field Epidemiology Track, Ministry of Health-Makerere University School of Public Health, P.O. Box 7072, Kampala, Uganda. ${ }^{2}$ School of Public Health, Makerere University College of Health Sciences, Kampala, Uganda. ${ }^{3}$ Rakai Health Sciences Program, Kampala, Uganda.

Received: 24 August 2016 Accepted: 2 March 2017

Published online: 14 March 2017

\section{References}

1. UNAIDS. UNAIDS World AIDS Day Report 2012. Geneva: UNAIDS; 2012 [www.unaids.org/sites/default/files/en/media/unaids/contentassets/ documents/epidemiology/2012/gr2012/JC2434_WorldAIDSday_results_en. pdf]. Accessed 20 Jan 2016.

2. Makumbi FE, Nakigozi G, Reynolds SJ, Ndyanabo A, Lutalo T, Serwada D, Nalugoda F, Wawer M, Gray R. Associations between HIV antiretroviral therapy and the prevalence and incidence of pregnancy in Rakai, Uganda. AIDS research and treatment. 2011:2011:519492.

3. Uganda AIDS Commission (UAC): HIV and AIDS Uganda Country Progress Report, 2013. Kampala: UAC; 2014. [http://www.unaids.org/sites/default/files/ country/documents/UGA_narrative_report_2015.pdf]. Accessed 14 Feb 2016.

4. Ministry of Finance. Millennium Development Goals Report for Uganda 2013. Drivers of MDG Progress in Uganda and Implications for the Post-2015 Development Agenda. Kampala: MoH; 2013. [http://www.ug.undp.org/content/ dam/uganda/docs/UNDPUg-2013MDGProgress\%20Report-Oct\%202013.pdf]. Accessed 23 Mar 2016.

5. Uganda Bureau of Statistics (UBOS): National Population and Housing Census, 2014. Kampala: UBOS; 2016. [https://unstats.un.org/unsd/ demographic/sources/census/wphc/Uganda/UGA-2016-05-23.pdf]. Accessed 15 June 2016

6. UNAIDS: The GAP Report. Genva: UNAIDS; 2015. [[http://www.unaids.org/ sites/default/files/media_asset/UNAIDS_Gap_report_en.pdf]. Accessed 20 May 2016.

7. UNAIDS: Global report: UNAIDS report on the global AIDS epidemic 2013. Geneva: UNAIDS; 2013. [http://www.unaids.org/sites/default/files/media_asset/ UNAIDS_Global_Report_2013_en_1.pdf]. Accessed 23 Feb 2016.

8. UNAIDS: New HIV infections are falling dramatically in Africa. Geneva: UNAIDS; 2010. [http://www.un.org/africarenewal/web-features/new-hiv-infections-arefalling-dramatically-africa]. Accessed 07 Feb 2016.

9. Shafer LA, Nsubuga RN, Chapman R, O'Brien K, Mayanja BN, White RG. The dual impact of antiretroviral therapy and sexual behaviour changes on HIV epidemiologic trends in Uganda: a modelling study. Sex Transm Infect. 2014;90(5):423-9.

10. Doyle JS, Degenhardt L, Pedrana AE, McBryde ES, Guy RJ, Stoove MA Weaver ER, Grulich AE, Lo YR, Hellard ME. Effects of HIV antiretroviral 
therapy on sexual and injecting risk-taking behavior: a systematic review and meta-analysis. Clin Infect Dis. 2014;59(10):1483-94.

11. Kaye DK, Kakaire O, Osinde MO, Lule JC, Kakande N. The impact of highly active antiretroviral therapy on high-risk behaviour of HIV-infected patients in sub-Saharan Africa. J Infect Dis Ctries. 2013;7(06):436-47.

12. Guindo OM, Liu A, Haba K. Knowledge, attitudes and practices of youth towards HIV/AIDS in Mali, West Africa. IJAPAS. 2014;1(1):12-23.

13. Agyemang S, Buor D, Tagoe-Darko E. The extent of knowledge about HIV/ AIDS among young people in the Ejura-Sekyedumase district of Ghana. J AIDS and HIV Research. 2012;4(11):241-7.

14. World Health Organisation (WHO): Progress on Global Access to HIV Antiretroviral Therapy, A Report on "3 by 5" and Beyond. Geneva: WHO; 2006. [http://www.who.int/hiv/fullreport_en_highres.pdf]. Accessed 23 Mar 2016.

15. World Health Organisation (WHO): World Health Statistics, 2015. Geneva: WHO; 2015. [http://apps.who.int/iris/bitstream/10665/170250/1/ 9789240694439_eng.pdf]. Accessed 20 Mar 2016.

16. UNAIDS: Global Statistics-2015. Geneva: UNAIDS; 2016. [https://www.aids. gov/hiv-aids-basics/hiv-aids-101/global-statistics/]. Accessed 18 Feb 2016.

17. UNAIDS: Global Aids Update 2016. Geneva: UNAIDS; 2016. [www.unaids. org/sites/default/files/media_asset/global-AIDS-update-2016_en.pdf]. Accessed 03 July 2016.

18. Opio A, Muyonga M, Mulumba N. HIV infection in fishing communities of Lake Victoria Basin of Uganda-a cross-sectional sero-behavioral survey. PLoS ONE. 2013;8(8), e70770.

19. Allison EH, Seeley JA. HIV and AIDS among fisherfolk: a threat to 'responsible fisheries'? Fish Fish. 2004;5(3):215-34.

20. Integrated Regional Information Networks (IRIN): Fishing communities in Uganda do not have adequate access to life-prolonging antiretroviral drugs (ARVs), posing a possible setback to the country's fight against HIV, new statistics reveal. Nairobi: IRIN; 2012. [http://www.irinnews.org/report/96894/ uganda-fishing-communities-missing-out-hiv-treatment]. Accessed 24 Feb 2016.

21. Uganda AIDS Commission (UAC). HIV and AIDS Uganda Country Progress Report 2014. Kampala: UAC; 2015.

22. Food and Agriculture Organization (FAO): Impact of HIV/AIDS on fishing communities. Geneva: FAO; 2004. [www.fao.org/3/a-y5922e.pdf]. Accessed 13 Mar 2016

23. Ministry of Agriculture, Animal Industry and Fisheries (MAAIF). Department Of Fisheries Resources Annual Report 2010/2011. Kampala: MAAIF; 2011.

24. Keizire BB: Opportunities and Options for Financing Fisheries Management in Uganda. [www.unuftp.is/static/fellows/document/boazprf.pdf]. Accessed 17 Oct 2016.

25. Macro Interantional Incorparation (MII): Child labor in the fishing industry in uganda. Kampala: MIl; 2011. [https://www.dol.gov/ilab/reports/pdf/ 2011CLFishingUganda.pdf]. Accessed 20 Mar 2016.

26. Tumwesigye NM, Atuyambe L, Wanyenze RK, Kibira SP, Li Q, WabwireMangen F, Wagner G. Alcohol consumption and risky sexual behaviour in the fishing communities: evidence from two fish landing sites on Lake Victoria in Uganda. BMC Public Health. 2012;12(1):1

27. Ministry of Health (MoH): Uganda AIDS Indicator Survey. Kampala: $\mathrm{MoH} ; 2011$ [https://dhsprogram.com/pubs/pdf/AIS10/AIS10.pdf]. Accessed 20 Mar 2016

28. Serwadda D, Sewankambo N, Carswell J, Bayley A, Tedder R, Weiss R, Mugerwa R, Lwegaba A, Kirya G, Downing R. Slim disease: a new disease in Uganda and its association with HTLV-III infection. Lancet. 1985;326(8460):849-52.

29. Nalugoda F, Wawer MJ, Konde-Lule JK, Menon R, Gray RH, Serwadda D, Sewankambo NK, Li C. HIV infection in rural households, Rakai District, Uganda. Health Transit Rev. 1997:127-140.

30. Health service delivery and other HIV/AIDS related interventions in the fisheries sector in Sub-Saharan Africa. [https://www.uea.ac.uk/documents/ 6347571/6549421/DEV+Report+and+Policy+Paper+2.pdf/c56602b2-509f4b10-9270-ee3a87694844]. Accessed 17 Oct 2016

31. Seeley J, Allison E. Overcoming barriers to delivery of effective health services for fisherfolk. Exchange on HIV/AIDS, Sexuality and Gender. 2005;1 (4):23-4.

32. Lubega M, Nakyaanjo N, Nansubuga S, Hiire E, Kigozi G, Nakigozi G, Lutalo T, Nalugoda F, Serwadda D, Gray R. Understanding the socio-structural context of high HIV transmission in kasensero fishing community, South Western Uganda. BMC Public Health. 2015;15(1):1033.

33. Kiwanuka N, Ssetaala A, Nalutaaya A, Mpendo J, Wambuzi M, Nanvubya A Sigirenda S, Kitandwe PK, Nielsen LE, Balyegisawa A. High incidence of HIV-1 infection in a general population of fishing communities around Lake Victoria, Uganda. PLoS ONE. 2014;9(5), e94932.
34. Béné C, Merten S. Women and fish-for-sex: transactional sex, HIV/AIDS and gender in African fisheries. World Dev. 2008;36(5):875-99.

35. Matovu JK, Denison J, Wanyenze RK, Ssekasanvu J, Makumbi F, Ovuga E, McGrath N, Serwadda D. Trends in HIV counseling and testing uptake among married individuals in Rakai, Uganda. BMC Public Health. 2013;13(1):1.

36. Wawer MJ, Gray RH, Sewankambo NK, Serwadda D, Paxton L, Berkley S, McNairn D, Wabwire-Mangen F, Li C, Nalugoda F. A randomized, community trial of intensive sexually transmitted disease control for AIDS prevention, Rakai, Uganda. AIDS. 1998;12(10):1211-25.

37. Gray RH, Makumbi F, Serwadda D, Lutalo T, Nalugoda F, Opendi P, Kigozi G, Reynolds SJ, Sewankambo NK, Wawer MJ. Limitations of rapid HIV-1 tests during screening for trials in Uganda: diagnostic test accuracy study. BMJ. 2007:335(7612):188.

38. Nakigozi G, Atuyambe L, Kamya M, Makumbi FE, Chang LW, Nakyanjo N, Kigozi G, Nalugoda F, Kiggundu V, Serwadda D. A qualitative study of barriers to enrollment into free HIV care: perspectives of never-in-care HIV-positive patients and providers in Rakai, Uganda. BioMed Res Int. 2013;2013.

39. Chang LW, Grabowski MK, Ssekubugu R, Nalugoda F, Kigozi G, Nantume B, Lessler J, Moore SM, Quinn TC, Reynolds SJ. Heterogeneity of the HIV epidemic in agrarian, trading, and fishing communities in Rakai, Uganda: an observational epidemiological study. Lancet HIV. 2016;3(8):e388-96.

40. Serwadda D, Wawer MJ, Musgrave SD, Sewankambo NK, Kaplan JE, Gray RH. HIV risk factors in three geographic strata of rural Rakai District, Uganda. AIDS. 1992;6(9):983-90.

41. Uganda AIDS Commission (UAC). National HIV and AIDS Strategic Plan 2007/8-2011/12. Kampala: UAC; 2012.

42. WHO: HIV and adolescents: Guidance for HIV testing and counselling and care for adolescents living with HIV Guidance document. Geneva: WHO; 2013. [http://apps.who.int/iris/bitstream/10665/94334/1/9789241506168_ eng.pdf?ua=1]. Accessed 4 May 2016.

43. Edelstein ZR, Santelli JS, Helleringer S, Schuyler AC, Wei Y, Mathur S, Song X, Lutalo T, Nalugoda F, Gray RH. Factors associated with incident HIV infection versus prevalent infection among youth in Rakai, Uganda. J Epidemiol Glob Health. 2015:5(1):85-91.

44. Grellier R, Tanzarn N, Lamberts D, Howard C. The Impact of HIV/AIDS on Fishing Communities in Uganda. London: DFID; 2004. [www.uac.go.ug/ Fisheries/impact.pdf]. Accessed 16 Oct 2016.

45. Njock J-C, Westlund L: Understanding the mobility of fishing people and the challenge of migration to devolved fisheries management. Achieving poverty reduction through responsible fisheries Lessons from West and Central Africa; 2008. [http://www.fao.org/3/a-i0448e/i0448e03. pdf]. Accessed 15 Oct 2016

46. Ministry of Health: Uganda Aids Indicator Survey 2011. Kampala: MoH; 2011. [http://health.go.ug/docs/UAIS_2011_REPORT.pdf]. Accessed 13 Mar 2016.

47. Smolak A. A meta-analysis and systematic review of HIV risk behavior among fishermen. AIDS Care. 2014;26(3):282-91.

48. Asiki G, Mpendo J, Abaasa A, Agaba C, Nanvubya A, Nielsen L, Seeley J, Kaleebu P, Grosskurth H, Kamali A. HIV and syphilis prevalence and associated risk factors among fishing communities of Lake Victoria, Uganda. Sex Transm Infect. 2011;87(6):511-5

49. Sanga Z, Kapanda G, Msuya S, Mwangi R. Factors influencing the uptake of Voluntary HIV Counseling and Testing among secondary school students in Arusha City, Tanzania: a cross sectional study. BMC Public Health. 2015;15(1):1.

50. Ndwiga T, Omwono M. A Study of Factors Influencing VCT Service Utilization among the Youths: A Case Study of Kapsabet Division, Nandi County, Kenya. World J AIDS. 2014;4(03):281.

51. Uganda AIDS Commission (UAC). The National HIV Prevention Strategy for Uganda 2011-15. Kampala: UAC; 2011.

52. Uganda AIDS Commission (UAC). The National Strategic Plan for HIV\&AIDS 2011/12 -2014/15 (revised). Kampala: UAC; 2012.

53. Seeley JA, Allison EH. HIV/AIDS in fishing communities: challenges to delivering antiretroviral therapy to vulnerable groups. AIDS Care. 2005;17(6):688-97.

54. Biddlecom AE, Munthali A, Singh S, Woog V. Adolescents' views of and preferences for sexual and reproductive health services in Burkina Faso, Ghana, Malawi and Uganda. Afr J Reprod Health. 2007;11(3):99.

55. Bailey RC, Moses S, Parker CB, Agot K, Maclean I, Krieger JN, Williams CF, Campbell RT, Ndinya-Achola JO. Male circumcision for HIV prevention in young men in Kisumu, Kenya: a randomised controlled trial. Lancet. 2007; 369(9562):643-56.

56. Gray RH, Kigozi G, Serwadda D, Makumbi F, Watya S, Nalugoda F, Kiwanuka $\mathrm{N}$, Moulton LH, Chaudhary MA, Chen MZ. Male circumcision for HIV 
prevention in men in Rakai, Uganda: a randomised trial. Lancet. 2007; 369(9562):657-66.

57. Uganda AIDS Commission (UAC). The HIV And AIDS Uganda Country Progress Report 2014. Kampala: UAC; 2015.

58. Samsuddin N, Ali A, Aris M, Aznan M, Draman S, Akter SFU. Social and HIV/AIDS risk behaviours in a fishing community. Int J Humanit Soc Sci. 2011;1(21):251-7.

59. Lubega M, Nakyaanjo N, Nansubuga S, Hiire E, Kigozi G, Nakigozi G, Lutalo T, Nalugoda F, Serwadda D, Gray R. Risk Denial and Socio-Economic Factors Related to High HIV Transmission in a Fishing Community in Rakai, Uganda: A Qualitative Study. PLoS ONE. 2015;10(8), e0132740.

60. Leigh BC. Alcohol and condom use: a meta-analysis of event-level studies. Sex Transm Dis. 2002;29(8):476-82.

61. Monascha R, Mahyb M: Young people: the centre of the HIV epidemic. 2006. [https://www.ncbi.nlm.nih.gov/pubmed/16921916]: Accessed 24 Feb 2016.

62. Cardoso LD, Malbergier A. Who is not using condoms among HIV-positive patients in treatment in the largest city in Brazil? AIDS Care. 2015;27(5):629-36.

Submit your next manuscript to BioMed Central and we will help you at every step:

- We accept pre-submission inquiries

- Our selector tool helps you to find the most relevant journal

- We provide round the clock customer support

- Convenient online submission

- Thorough peer review

- Inclusion in PubMed and all major indexing services

- Maximum visibility for your research

Submit your manuscript at www.biomedcentral.com/submit 